\title{
Evaluation of geothermal potential in some parts of Bida Basin of Nigeria using Curie point depths and heat flow from spectral analysis of aeromagnetic data
}

\author{
Matthew Tersoo Tsepav ${ }^{1,3}$ and A. Mallam ${ }^{2}$ \\ ${ }^{1}$ Department of Physics, Ibrahim Badamasi Babangida University, Lapai \\ ${ }^{2}$ Department of Physics, University of Abuja, Abuja \\ ${ }^{3}$ Department of Physics, Federal University of Lafia, Lafia. \\ E-mail: tsematoo@yahoo.com
}

Received 5 June 2020, Revised 20 August 2020, Published 30 September 2020

\begin{abstract}
The Centroid method of Spectral Depth analysis was used to evaluate the Curie point depth (CPD), Geothermal Gradient and Heat Flow in some parts of the Bida Basin of Nigeria with a view to determining the energy potential of the area. The reduced-to-pole aeromagnetic data was divided into 16 overlapping ensembles and Fast Fourier Transformed to decompose the anomalies into their energy and wavenumber components using Oasis montaj software. The radial power spectrum was calculated for each of the grid points with the locations of the centres of the ensembles and a plot of Energy spectrum versus frequency was carried out to generate two different gradients: $s_{1}$ and $s_{2}$ representing different depth source models. These gradients were used to evaluate the average depth to the top of the deepest crustal block, $\mathrm{Z}_{\mathrm{t}}$, depth to the centroid of the deepest crustal block, $Z_{0}, C P D$, Geothermal Gradient and Heat flow. From the results obtained, the CPD varied from 2.59 to $8.23 \mathrm{Km}$ while the thermal gradient and heat flow in the area revealed values ranging from 70.45 to $224.15{ }^{\circ} \mathrm{CKm}^{-1}$ and 176.13 to $560.37 \mathrm{mWm}^{-2}$ respectively. The results of the contouring in conjunction with the CPD, geothermal gradient and the heat flow values have shown that the area has a greater energy potential in the south-eastern block of Katonkarfi, with shallow CPD and high geothermal gradient and heat flow. These results could be incorporated in the GIS and available geological, geophysical and geochemical information of the area to facilitate selection of the optimum site for energy exploration.
\end{abstract}

Keywords: Spectral analysis, Curie point depth, geothermal potential, Heat flow

\section{Introduction}

The Curie point is the temperature at which the spontaneous magnetization of a material vanishes and magnetic minerals show paramagnetic susceptibility. It is approximately $580{ }^{\circ} \mathrm{C}$ for magnetite at atmospheric pressure and varies from region to region depending on the geological composition and mineral content of the rocks. The 
depth at which temperature reaches the Curie point is assumed to be the bottom of the magnetized bodies in the earth crust; hence, one can normally expect that shallow Curie point depths (CPD) are the regions which have high geothermal potential. These regions might comprise young volcanisms and thin crust (Aydin and Oksum 2010). The assessment of variations in the Curie depth of an area can provide valuable information about the regional temperature distribution at various depths and the potential of subsurface geothermal energy within the area could be deciphered.

Bida basin is situated predominantly in Niger State with extensions into Kogi State and Nigeria's Federal Capital Territory, Abuja. The state has three hydro power generating stations in Kainji, Shiroro and Jebba with a fourth one almost competed in Zungeru, yet this energy is supplied to the National Grid while the state continuously suffer energy needs. Locating areas with high geothermal potential for further exploration and subsequent exploitation would serve as to augment the current energy supply in the area.

The use of aeromagnetic data to estimate CPD is an old but effective method that is being used widely in various parts of the world. With the Curie depths estimated, the thermal gradient and geothermal heat flow could be calculated using appropriate mathematical expressions, thus giving the geothermal potential of an area. Several researchers have effectively utilised the method successfully in determining potential areas for geothermal exploration. For instance, Bernadette et al.; (2020) interpreted the aeromagnetic data of Gubio area, Chad Basin, Nigeria, employing spectral analysis technique with the aim of estimating the Curie point depth, geothermal gradient and heat flow in order to determine the geothermal nature of the area. The results gave Curie point depth values ranging from 10.63 to $20.07 \mathrm{~km}$, with the deepest portion at the northeast, while the shallowest depth was observed in the southeastern part of the study area. The estimated geothermal gradient ranges from 28.90 to $54.57^{\circ} \mathrm{C} \mathrm{km}-1$ with an average value of $40.26{ }^{\circ} \mathrm{C} \mathrm{km}-1$, with low values in the northeast direction, and increases towards southeast. The estimated heat flow values ranged from 72.24 to $136.43 \mathrm{~mW} \mathrm{~m}-2$ with an average value of $100.65 \mathrm{~mW} \mathrm{m-2}$.

Anakwuba and Chinwuko (2015) obtained Curie temperature isotherm depth in northern Chad basin which varied between $21.45 \mathrm{~km}$ and $31.52 \mathrm{~km}$ with geothermal gradients associated with it ranging between 17.45 and $25.64{ }^{\circ} \mathrm{C} \mathrm{km}-1$ and the corresponding mantle heat flow of about $46.00 \mathrm{~mW} \mathrm{~m}-2$ and $67.60 \mathrm{~mW} \mathrm{~m}-2$.

Obande et al. (2014) also applied spectral analysis of aeromagnetic data for geothermal prospecting in the north-east Nigeria. The range of CPD obtained varied from $6 \mathrm{~km}$ to 12 $\mathrm{km}$. The highest heat flow value and the shallowest CPD occurred near the Wikki thermal springs which were recommended as having a great energy potential with a shallow CPD and very high heat flow values.

In an attempt to map the CPD in the Northern Red Sea rift of Egypt, Saleh et al. (2013) used the spectral analysis of the aeromagnetic data to estimate CPD and heat flow map for the area. They found the CPD varying from $5 \mathrm{~km}$ to $20 \mathrm{~km}$. They therefore, suggested the $5 \mathrm{~km}$ associated with the high heat flow as the most promising area for geothermal exploration. 
Eletta and Udensi (2012) investigated the CPD isotherm from the aeromagnetic data to prepare a preliminary potential map of geothermal resources in the Eastern Sector of Central Nigeria. They showed that the highest prospect areas were located in the southwest parts of the study area.

Karastathis et al. (2010) combined a travel-time inversion of a micro-seismic dataset together with a CPD analysis based on the aeromagnetic data to decipher the origin of the geothermal fields and volcanic centres in central Greece. They also found that a possible magma chamber can be presumed by detecting a low seismic velocity volume at depths below $8 \mathrm{~km}$ and the CPD estimation at about 7-8-km depth as well.

Nwankwo and Ekine (2009) investigated geothermal gradients of Chad Basin, Nigeria, using bottom hole temperature logs and obtained a geothermal gradient in the range of $30-44{ }^{\circ} \mathrm{C} \mathrm{km}-1$ with an average value of $34{ }^{\circ} \mathrm{C} \mathrm{km}-1$.

Tanaka et al. (1999) determined CPD based on the spectral analysis of magnetic anomaly data. They used many heat flow data from the boreholes and applied the centroid method to obtain an estimated CPD which varied from 9 to $46 \mathrm{~km}$. They also predicted CPD from heat flow data which agreed with the results of the CPD analysis of magnetic data.

In an effort to understand the nature and extent of the regional geothermal system at a depth beneath an area in Greece, Tselentis (1991) calculated CPD from aeromagnetic and heat flow data by constructing the Curie isotherms. The results showed that the CPD varied considerably between $20 \mathrm{~km}$ towards western Greece and about $10 \mathrm{~km}$ beneath the Aegean.

Bhattacharyya and Leu (1975) in their research mapped Curie point isothermal surface for geothermal reconnaissance of the Yellow stone National Park in USA and obtained an estimated CPD of $4-8 \mathrm{~km}$.

Owing to the vast need for energy and the inadequate supply of same, any study regarding the location of geothermal potential zones within the region is highly important as a reconnaissance stage of geothermal exploration program. The paper therefore, applies the centroid method of spectral depth analysis of the aeromagnetic data of Bida basin to determine CPD in some parts of the Basin to be able to estimate areas of high heat flow values and identify them as prospective geothermal zones.

\section{Geology of Bida Basin}

The Bida (Figure 1) consists of the Bida and Lokoja formations which were produced during the Campanian, the Sakpe, Enagi, Batati, Patti and Agbaja formations that were created during the Maastrichtian. Stratigraphic successions (Figure 2) in the Bida Basin indicate that Bida Formation is divided into the Doko Member and the Jima Member with the Doko Member located $16 \mathrm{~km}$ south of Bida and having a basal unit that consists of $80 \mathrm{~m}$ massive and flat bedded arkoses and coarse to medium sandstone with breccia horizons (Olaniyan et al., 2012). The sandstones of the Jima Member, according to Adeleye (1989), are dominantly quartzose, non-arkosic and brownish. Thin intercalations of poorly sort, hard, whitish, argillaceous sandstones are locally present in the lower parts of the Jima subfacies. The Lithologic units in Lokoja Formation range from 
conglomerates, coarse to fine grained sandstones, siltstones and claystones in the Lokoja area (Akande et al., 2005). Sub angular to subrounded cobbles, pebbles and granule sized quartz grains in the units are frequently distributed in a clay matrix. The Sakpe Formation comprises mainly oolitic and pisolitic ironstones with sandy claystones locally, at the base, followed by dominantly oolitic ironstone which exhibits rapid facies changes across the basin at the top (Adeleye, 1973).

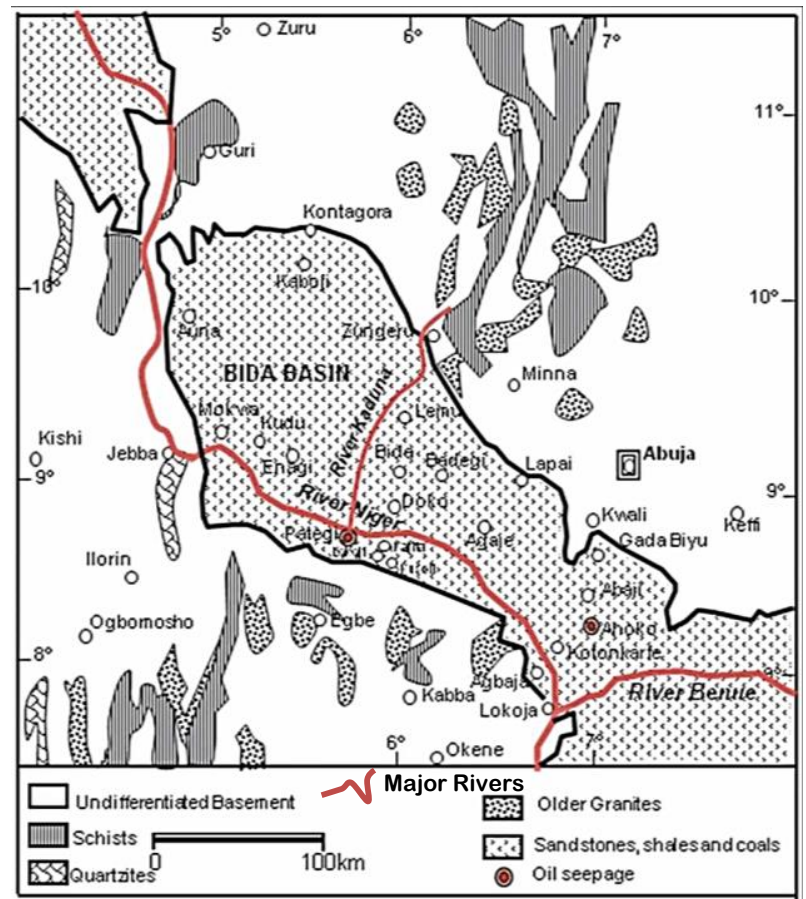

Figure 1. Geology and Location Map of Bida Basin and its Surroundings (Obaje, 2009)

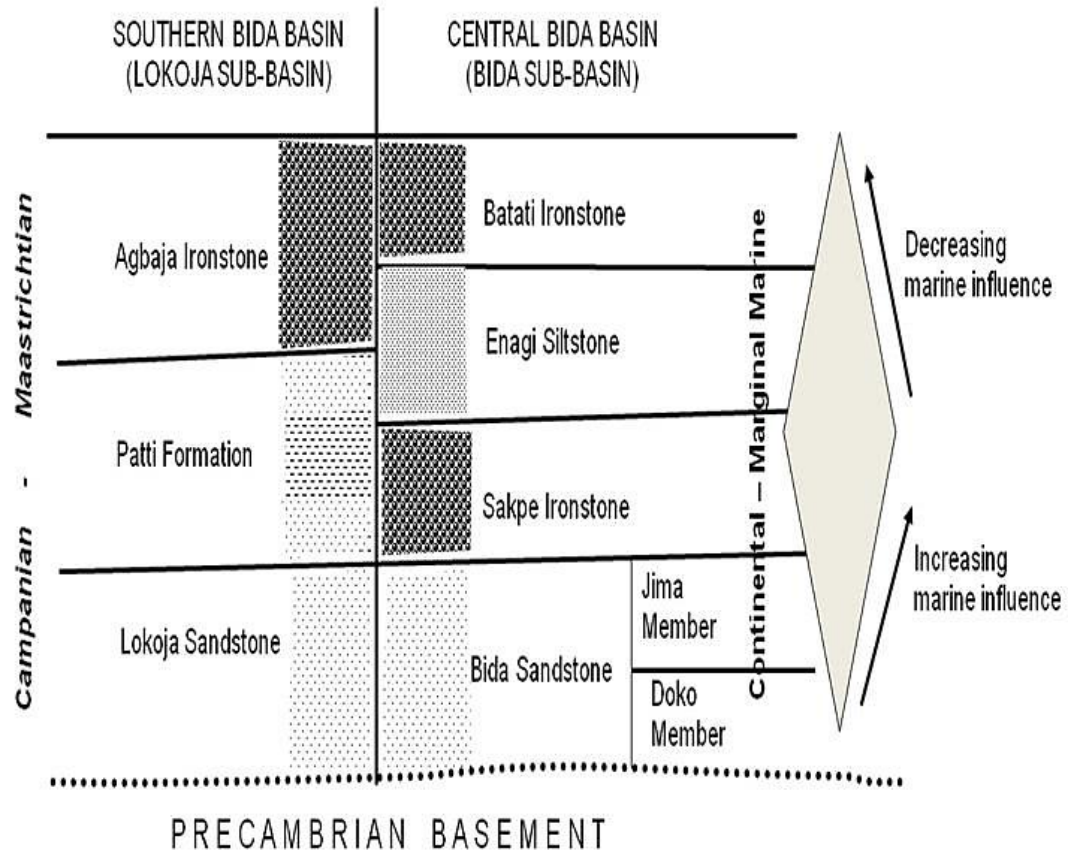

Figure 2. Stratigraphic successions in the Bida Basin (after Obaje, 2009) 
The Enagi Formation as described by Obaje (2009), on the other hand, consists mainly of siltstones and correlates with the Patti Formation in the Lokoja sub-Basin. Other subsidiary lithologies include sandstone-siltstone with some claystones. Fossil leaf impressions and rootlets have been found within the formation. The formation ranges in thickness between $30 \mathrm{~m}$ and $60 \mathrm{~m}$. Mineral assemblage consists mainly of quartz, feldspars and clay.

The Batati formation constitutes the uppermost units in the sedimentary sequence of the Bida Basin. It consists, according to Obaje et al. (2013), of argillaceous, oolitic and goethitic ironstones with ferruginous claystone and siltstone intercalations and shaly beds which occur in minor proportions some of which have yielded near shore shallow marine to fresh water fauna. The outcrops of the Patti Formation occur between Koton-Karfi and Abaji. This formation consists of sandstones, siltstones, claystones and shales interbedded with bioturbated ironstones with the argillaceous units predominating in the central parts of the basin. The Agbaja Formation forms a persistent cap for the Campanian Maastrichtian sediments in the Southern Bida Basin as a lateral equivalent of the Batati Formation on the northern side of the basin. It consists of sandstones and claystones interbedded with oolitic, concretionary and massive ironstone beds in this region.

\section{Materials and Methods}

\subsection{Data Acquisition and processing}

The 2009 IGRF corrected total magnetic field intensity data (Figure 3) was acquired from the Nigeria Geological Survey Agency while Oasis montaj Software was used for the analysis while the centroid method of the Spectral Depth Analysis was used to determine the CPD within the study area.

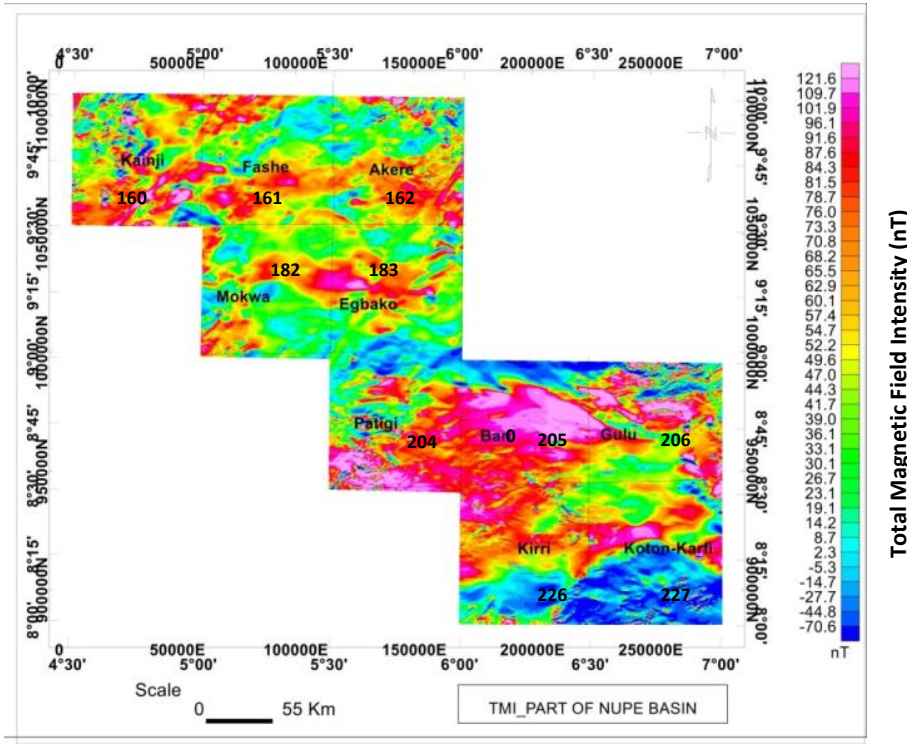

Figure 3. 2009 IGRF Corrected TMI data on sheets covering Parts of Bida/Nupe Basin.

Imaging processing and data interpretation require the data to be changed to an equally spread out two-dimensional (2-D) arrangement known as gridding. Since the collected 
$X Y Z$ data were over broadly segregated parallel lines which could have led to certain points being extrapolated, it is important that the data be gridded.

The TMI map in Figure 3 shows the general magnetic anomaly of the basement rocks and the inherent variation in the magnetic field intensity. This data was reduced to pole to transform the magnetic anomaly caused by an arbitrary source into the anomaly that the same source would produce if it were located at the magnetic pole and magnetized by induction only. Reduction to pole removes the dependence of magnetic field data on the magnetic inclination of the geomagnetic field, by transforming the measured magnetic field anomaly into the anomaly that would have been measured if the magnetic field had been collected from the North Pole $\left(I=90^{\circ}\right)$. RTP simplifies the shapes of magnetic anomalies and makes them appear like positive anomalies located directly above the source expected for induced magnetized bodies (Gunn, 1995). Oasis Montaj software was used to reduce the total magnetic field intensity data to pole as shown in Figure 4.

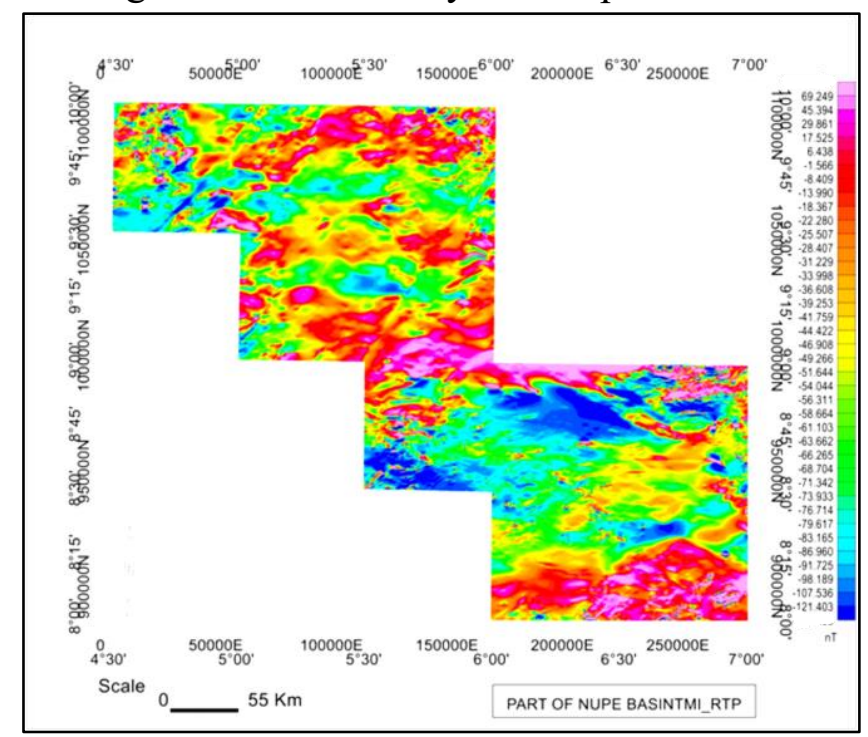

Figure 4: 2009 IGRF Corrected TMI data of Parts of Bida/Nupe Basin Reduced to Pole.

Spectral analysis method was employed in order to estimate the Curie point depth, geothermal gradient and the heat flow in the area. To perform the analysis, the study area was subdivided into sixteen spectral blocks and Fast Fourier Transform (FFT) then performed on each of the windows to decompose the anomalies into their energy and wavenumber components. Thereafter, the radial power spectrum was calculated for each of the grid points with the locations of the centres of the ensembles from 1 to 16 as shown in Figure 5. Afterward, a plot of Energy spectrum versus frequency in cycles per km was carried out using MatLab Plotter and straight lines were then fit to the energy spectrum, both in the higher and lower portions of the graphs to generate two different gradients: $\mathrm{s}_{1}$ and $\mathrm{s}_{2}$ representing different depth source models (Appendix A).

\subsection{Estimation of Curie point depth, geothermal gradient and heat flow}

For each block, two linear segments were drawn from each graph, and their gradients calculated using: 


$$
\text { slope }\left(s_{1}, s_{2}\right)=\frac{\text { Log of Spectral Energy }}{\text { Frequency }}
$$

The depth to the centroid $\left(Z_{0}\right)$ and the depth to the top boundary $\left(Z_{\mathrm{t}}\right)$ were also respectively calculated from the following equations:

$$
z_{0}=-\frac{s_{1}}{4 \pi}
$$

and

$$
z_{t}=-\frac{s_{2}}{4 \pi}
$$

where $s_{1}$ and $s_{2}$ are slopes of the first and second segment of the plot, respectively, and the negative sign indicates the depth to the subsurface.

The Curie point depth $\left(Z_{\mathrm{b}}\right)$, was evaluated from the equation:

$$
Z_{b}=2 Z_{0}-Z_{t}
$$

The geothermal gradient $\frac{d y}{d x}$ between the Earth's surfaces is defined according to Stampolidis et al.: (2005) and Hinze et al.: (2013) as

$$
\frac{d T}{d Z}=\frac{\theta}{Z_{b}}
$$

where $\theta=580{ }^{\circ} \mathrm{C}$ is the Curie temperature for magnetite (Tanaka et al.; 1999)

For determination of the surface heat flow, the value of the average thermal conductivity of the crustal rocks $\lambda=2.5 \mathrm{Wm}^{-1}{ }^{\circ} \mathrm{C}^{-1}$ (Tanaka et al.; 1999) was used in the equation:

$$
q=\lambda\left(\frac{\theta}{Z_{b}}\right)
$$

The OriginPro8 software was used to construct the 2D Curie isotherm depth as well as the geothermal gradient and heat flow of the study area, respectively. Equation 6 shows the relationship between the Curie isotherm depth $\left(Z_{b}\right)$ and the heat flow $(q)$ (Turcotte and Schubert, 1982)

Spectral Depth Analysis was applied to the total magnetic field intensity data covering parts of Bida Basin to determine the depth to basement rocks and by extension the CPD. Regional-residual data separation was performed to distinguish the residual from the regional data. The residual data was then divided into sixteen (16) overlapping spectral windows or ensembles as shown in Figure 5 and Fast Fourier Transform (FFT) was then performed on each of the windows to decompose the anomalies into their energy and wavenumber components using Oasis montaj software. The radial power spectrum was then calculated for each of the grid points. The locations of the centres of the ensembles are indicated on the map in Figure 5 from 1 to 16.

The CDP, geothermal gradient and heat flow were contoured for qualitative interpretation as shown in Figures 6, 7 and 8 respectively. 


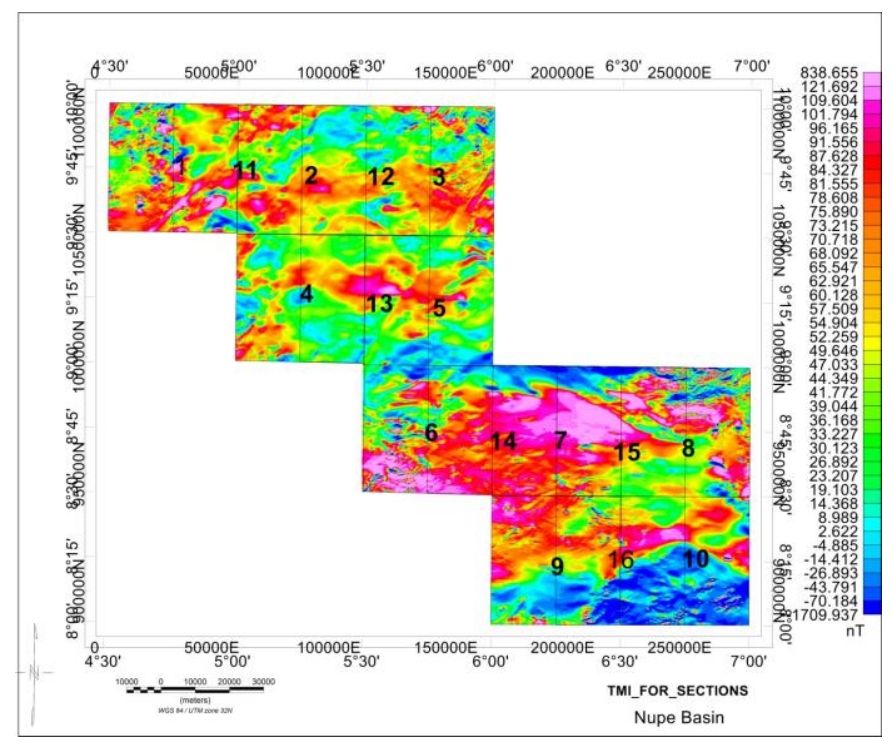

Figure 5. Spectral windows showing the centres of the ensembles

\section{Results and Discussion}

The 2D TMI map of the study area shows that TMI values range from - 70.6 to 121.6 $\mathrm{nT}$, which shows that the area is magnetically heterogeneous in nature. Areas of very strong TMI values (101.9-121.6 nT) are probably caused by near-surface igneous or metamorphic rocks of high magnetic susceptibility values. There is also the probability of ironstones present in the basin bringing up strong magnetic susceptibilities. The areas with very weak magnetic susceptibility values ranging between -14.7 and $-70.6 \mathrm{nT}$ are most likely due to thick sediments and presence of other non-magnetic sources like Sandstones.

The reduction to pole, RTP, (Fig. 4) obtained from the TMI map ranges from - 121.4 to $69.2 \mathrm{nT}$. The RTP map was subdivided into sixteen equal overlapping spectral blocks (Fig. 5). Appendix A shows the graphs for the spectral blocks which revealed two linear segments which were recognized for every block as two magnetic source layers in the study area. The gradient of the deep and shallow line segments were evaluated using equation (1), and the depth to centroid $\left(Z_{0}\right)$ and depth to top boundary $\left(Z_{t}\right)$ were evaluated using equations (2) and (3). Curie point depth $(Z b)$, thermal gradient ( dT/dZ) and the heat flow $(q)$ of the study area were also calculated from equations (4), (5) and (6) respectively. Table 1 shows these values for each block with their locations according to latitudes and longitudes.

OriginPro8 software was used to extrapolate and convert the data into matrix format and then contoured in a gridded form for the CPD, Thermal gradient and Heat flow accordingly, for a qualitative interpretation. 
Table 1: Table of spectral depth for the 16 ensembles of shallow and deeper magnetic sources.

\begin{tabular}{|c|c|c|c|c|c|c|c|c|c|c|}
\hline 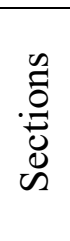 & 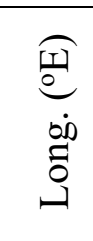 & 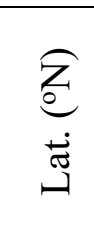 & 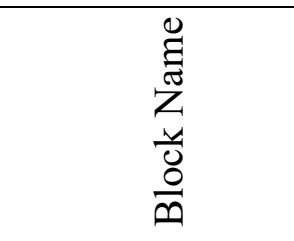 & $\begin{array}{l}\text { क्ञn } \\
0 \\
\frac{\partial}{\infty}\end{array}$ & $\begin{array}{l}\text { ह̂n } \\
0 \\
\frac{0}{0} \\
\frac{0}{n}\end{array}$ & $\begin{array}{l}\text { Depth to Centroid } \\
\qquad z_{0}(\mathrm{~km})\end{array}$ & $\begin{array}{l}\text { Depth to Top Boundary } \\
\qquad z_{t}(\mathrm{~km})\end{array}$ & $\begin{array}{c}\text { Curie } \\
\text { Depth } \\
z_{b} \\
(\mathrm{~km})\end{array}$ & $\begin{array}{c}\text { Geothermal } \\
\text { Gradient } \frac{d T}{d Z} \\
{ }^{\circ} \mathrm{CKm}^{-1}\end{array}$ & $\begin{array}{c}\text { Heat } \\
\text { flow (q) } \\
\mathrm{mWm}^{-2}\end{array}$ \\
\hline 1 & 4.75 & 9.75 & Kainji & 42.80 & 11.30 & 3.41 & 0.90 & 5.92 & 98.05 & 245.11 \\
\hline 2 & 5.25 & 9.75 & Fashe & 41.90 & 21.60 & 3.34 & 1.72 & 4.95 & 117.12 & 292.80 \\
\hline 5 & 5.75 & 9.25 & Egbako & 40.50 & 12.70 & 3.22 & 1.01 & 5.44 & 106.66 & 266.65 \\
\hline 6 & 5.75 & 8.75 & Patigi & 34.00 & 11.60 & 2.71 & 0.92 & 4.49 & 129.16 & 322.91 \\
\hline 7 & 6.25 & 8.75 & Baro & 47.00 & 14.00 & 3.74 & 1.11 & 6.37 & 91.06 & 227.65 \\
\hline 8 & 6.75 & 8.75 & Gulu & 37.50 & 7.71 & 2.99 & 0.61 & 5.36 & 108.26 & 270.65 \\
\hline 9 & 6.25 & 8.25 & Kirri & 30.90 & 3.19 & 2.46 & 0.25 & 4.67 & 124.29 & 310.73 \\
\hline 14 & 6.00 & 8.75 & Patigi/Baro & 49.00 & 13.90 & 3.90 & 1.11 & 6.70 & 86.62 & 216.55 \\
\hline 15 & 6.50 & 8.75 & Baro/Gulu & 58.00 & 12.60 & 4.62 & 1.00 & 8.23 & 70.45 & 176.13 \\
\hline 16 & 6.50 & 8.25 & Kiri/Kotonkarfi & 34.80 & 5.31 & 2.78 & 0.42 & 5.12 & 113.31 & 283.28 \\
\hline \multicolumn{8}{|r|}{ Average values } & 5.17 & 120.66 & 301.66 \\
\hline
\end{tabular}


Figure 6 and Table 1 show the two-dimensional (2D) map of the Curie point depth of the study area and depth values ranging from shallowest depth of $2.59 \mathrm{~km}$ on Block 10 which is the Kotonkarfi block to the deepest depth of $8.23 \mathrm{~km}$ around the Baro/Gulu interface with average value of $5.17 \mathrm{~km}$. A further look at the map reveals that the deepest Curie point depth lies around the western part of the area corresponding to the areas around southern Kainji Block. The shallowest CPD was also delineated around the southeastern part of the area around the Kotonkarfi block of the region.

The 2D geothermal gradient and heat flow in the area, shown in Figures 7 and 8 have respectively revealed the highest values around the Kotonkarfi Block and the lowest values around the Baro/Gulu interface Block. The range of the calculated geothermal gradient is from 70.45 to $224.15^{\circ} \mathrm{C} \mathrm{km}^{-1}$ with an average value of $120.66{ }^{\circ} \mathrm{C} \mathrm{km}^{-1}$ (Table 1). The heat flow values range from 176.13 to $560.37 \mathrm{~mW} \mathrm{~m}^{-2}$ with an average value of $301.66 \mathrm{~mW} \mathrm{~m}^{-2}$ (Table 1). These results indicate that the Curie point depth, geothermal gradient and heat flow within the basin are not on a horizontal level surface but undulating.

Results of the Curie point depth compared with heat flow values have confirmed the distinct inverse linear relationship between the parameters. It can be inferred that the regions with high temperature gradient and high heat flow (Figures 7 and 8) are associated with shallow CPD Figure 6. It has been observed that an anomalous high temperature gradient and heat flow is a characteristic of a zone with substantial geothermal energy. The quantitative change in Curie depth observed in Fig. 5 implies that the heat flow in the study area is not uniform. This shows that region of high geothermal energy is characterized by an anomalous high temperature gradient and heat flow. The variation in the CPD is believed to be associated with the geological conditions (Ross et al. 2006). The CPDs at volcanic and geothermal areas are shallower (Obande et al.; 2014) while heat flow of about $80-100 \mathrm{~mW} / \mathrm{m}^{2}$ according to Jessop et al.; (1976) indicates a geothermal anomalous conditions.

The study area is generally found to have a good energy potential but with greater potential in the south-east block of Katonkarfi, corresponding to shallow CPD and high geothermal gradient and heat flow.

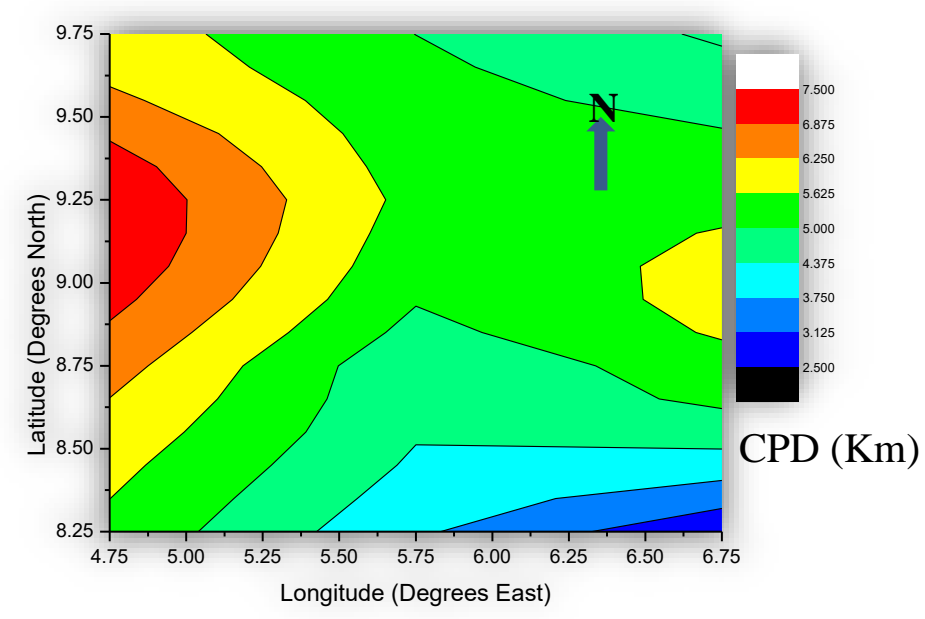

Figure 6. Extrapolated contour map of CDP using OriginPro8 Contouring Software 


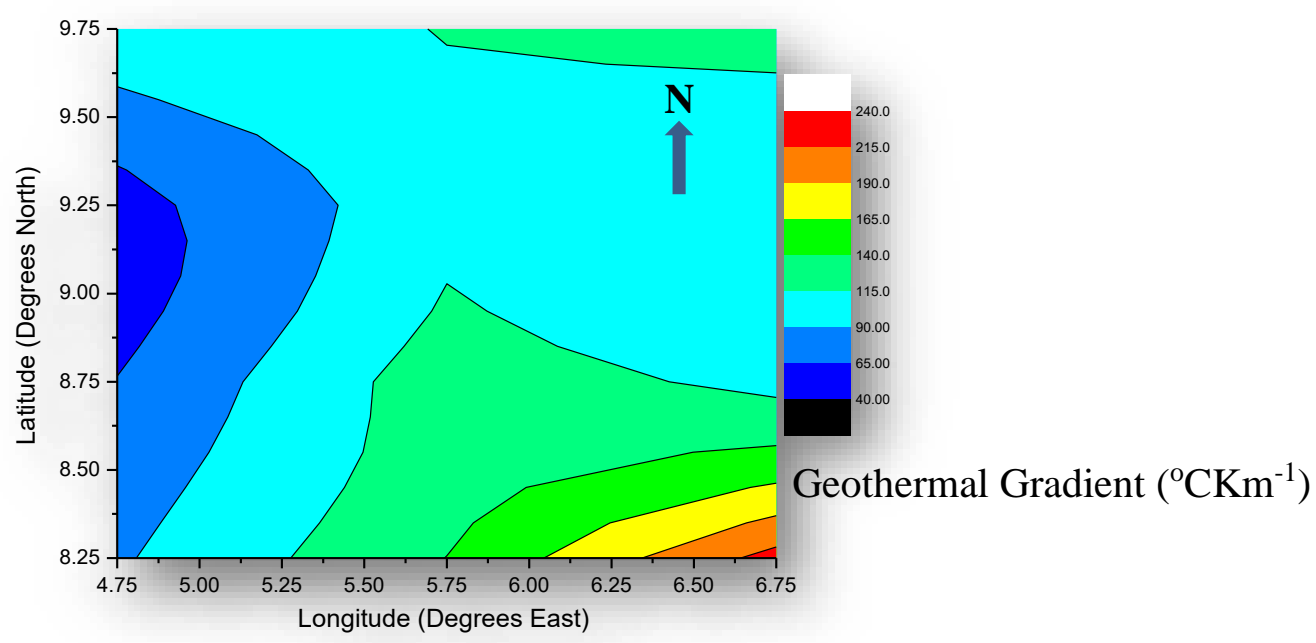

Figure 7. Extrapolated contour map of geothermal gradient using OriginPro8 Contouring Software

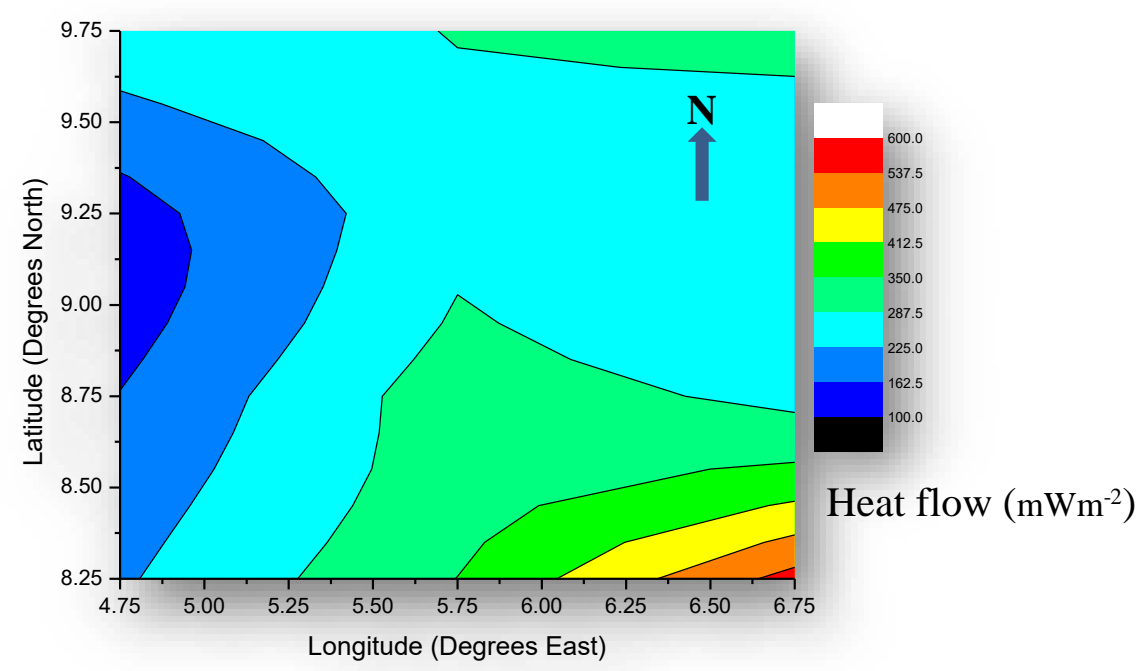

Figure 8. Extrapolated contour map of the heat flow using OriginPro8 Contouring Software

\section{Conclusion}

The Centroid method of Spectral Depth analysis was used to evaluate the Curie point depth (CPD), Geothermal Gradient and Heat Flow in some parts of the Bida Basin of Nigeria. The reduced-to-pole aeromagnetic data were divided into 16 overlapping square blocks and Fast Fourier Transform (FFT) was then performed on each of the windows to decompose the anomalies into their energy and wavenumber components using Oasis montaj software. The radial power spectrum was calculated for each of the grid points with the locations of the centres of the ensembles and labeled 1 to 16 as shown in Figure 5. Afterward, a plot of Energy spectrum versus frequency in cycles per km was carried out using MatLab Plotter and straight lines were then fit to the energy spectrum, both in 
the higher and lower portions of the graphs to generate two different gradients: $\mathrm{s}_{1}$ and $\mathrm{s}_{2}$ representing different depth source models (Appendix A).

The average depth to the top of the deepest crustal block, $\mathrm{Zt}$, was first computed by linear fitting to the second longest wavelength segment of the power spectrum of aeromagnetic data. Then, depth to the centroid of the deepest crustal block, $\mathrm{Z}_{0}$, was computed by linear fitting to the longest wavelength segment of the power spectrum of the aeromagnetic data. The depth to the magnetic top, CPD, Geothermal Gradient and Heat flow were obtained using equations 3, 4, 5 and 6 respectively. From the results obtained, the CPD varied from 2.59 to $8.23 \mathrm{Km}$. The Curie temperature of magnetite was used to determine the thermal gradient and heat flow in the area which revealed values ranging from 70.45 to $224.15{ }^{\circ} \mathrm{CKm}^{-1}$ for thermal gradient and 176.13 to $560.37 \mathrm{mWm}^{-}$ ${ }^{2}$ for the heat flow. The results of the contouring as well as the calculation of the CPD, geothermal gradient and the heat flow have shown that the area has a great energy potential in the south-eastern block of Katonkarfi, with shallow CPD and high geothermal gradient and heat flow.

The results of this study could be integrated in the GIS of the area, together with available geological, geophysical and geochemical information to facilitate selection of the optimum site for energy exploration.

\section{Acknowledgements}

Ibrahim Badamasi Babangida University, Lapai Hydrocarbon Research Project and Prof. N.G. Obaje for granting third party access to the data at no cost, And to TETFund for sponsoring part of the research.

\section{Appendix A: Graphs of Energy Spectral versus Frequency.}
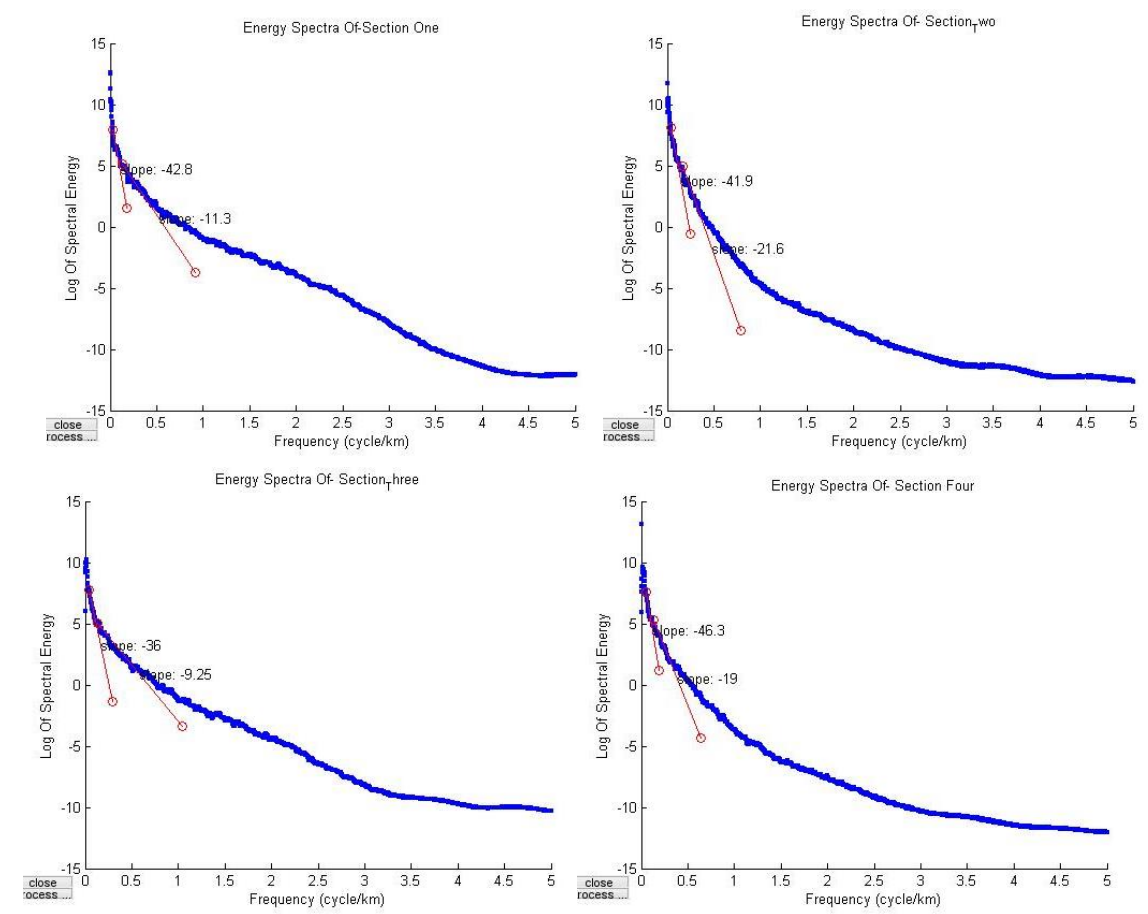

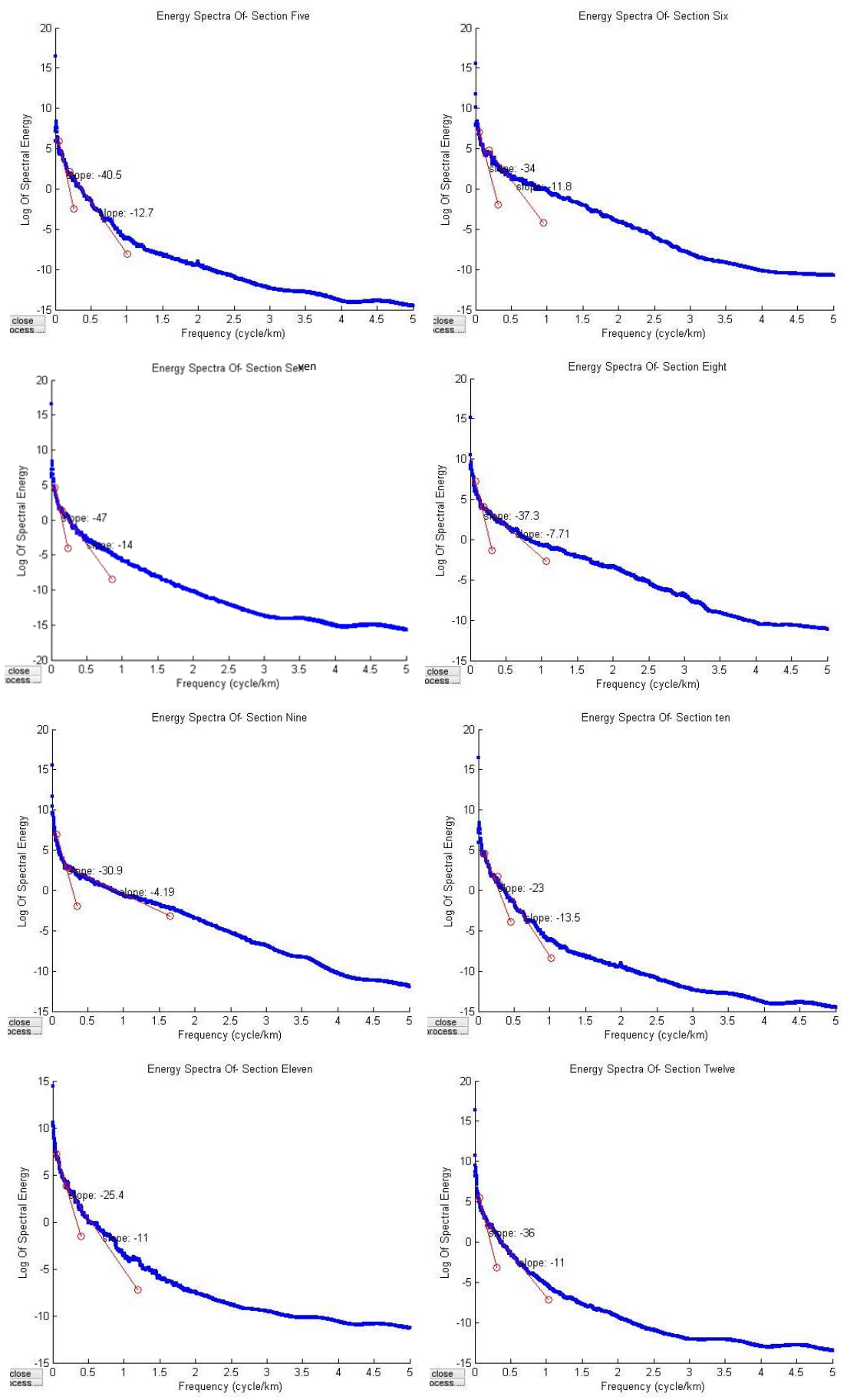


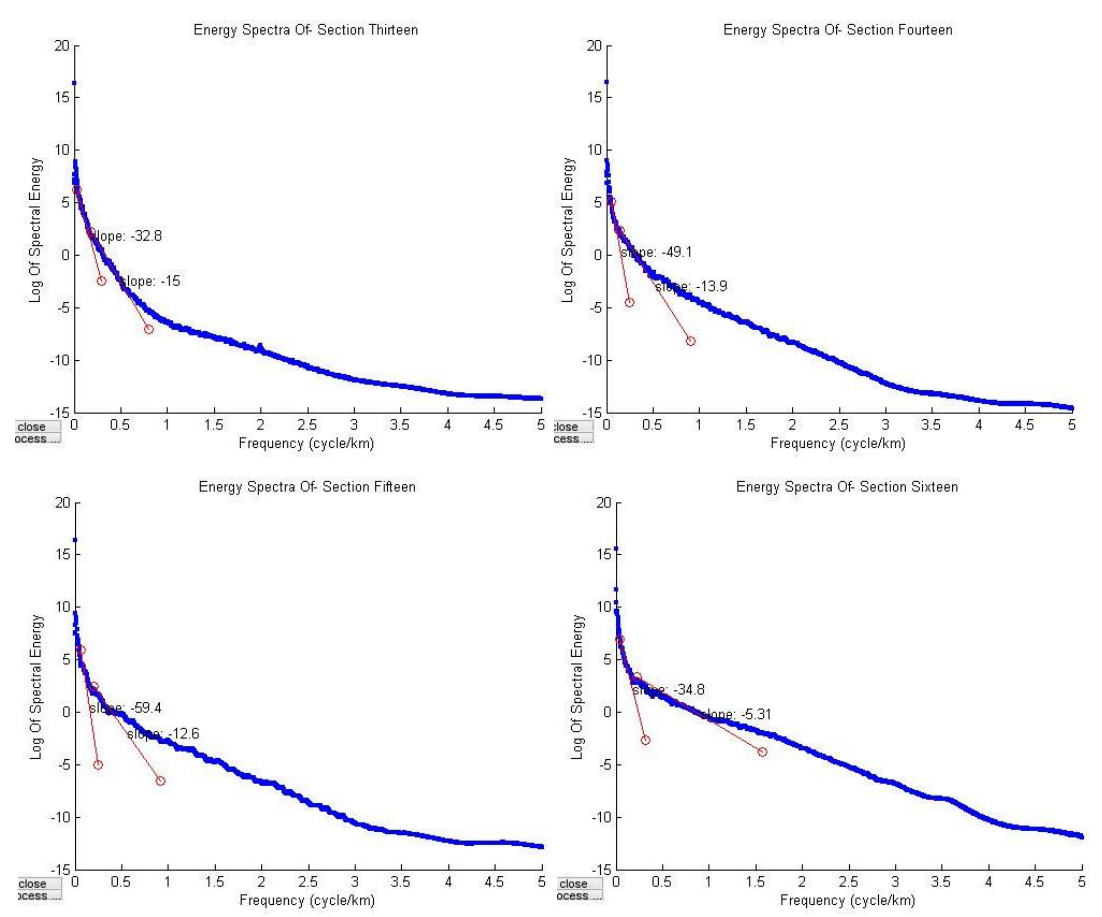

\section{References}

Adeleye, D. R. "Origin of ironstones, an example from the middle Niger Basin, Nigeria". Journal of Sedimentary Petrology, 43, 709-727, 1973.

Adeleye, D. R. The Geology of the middle Niger basin. In: Kogbe, C.A. (Ed.), Geology of Nigeria, second ed. Elizabethan Publishing Co., Lagos, 335-33, 1989.

Akande, S.O., Ojo, O.J., Erdtmann, B.D. and Hetenyi, M. "Paleoenvironments, organic petrology and Rock-Eval studies on source rock facies of the Lower Maastrichtian Patti Formation, southern Bida Basin, Nigeria". Journal of African Earth Sciences, 41, 394-406, 2005.

Anakwuba EK, Chinwuko AI. "One dimensional spectral analysis and Curie depth isotherm of Eastern Chad Basin, Nigeria". Journal of Natural Science Resources, 5(19):14-22, 2015.

Aydin I, Oksum E. "Exponential approach to estimate the Curie-temperature depth". Journal of Geophysical Engineering 7:113-125, 2010.

Bernadette C. Dimgba, Daniel N. Obiora, Johnson U. Abangwu and Desmond O. Ugbor "Study of Curie point depth and heat flow from spectral analysis of aeromagnetic data for geothermal potential of Gubio, Chad Basin". Nigeria. Springer Nature Applied Sciences 2:1351 https://doi.org/10.1007/s42452-020-3146-9, 2020.

Bhattacharyya BK, Leu LK. "Spectral analysis of gravity and magnetic anomalies due to rectangular prismatic bodies”. Geophysics 41:41-50, 1977.

Eletta BE, Udensi EE. "Investigation of the Curie point isotherm from the magnetic fields of eastern sector of central Nigeria". Geosciences 2(4):101-106, 2012.

Gunn PJ. "An algorithm for reduction to pole that works at all magnetic latitudes". Exploration Geophysics 26:247-254, 1995.

Hinze WJ, VonFrese RRB, Saad AH Gravity and magnetic exploration. Cambridge 
University Press, Cambridge, 2013.

Jessop AM, Hobart MA, Sclater JG. "The world heat flow data collection 1975, Geothermal Services of Canada”. Geothermal Service 50:55-77, 1976.

Karastathis VK, Papoulia J, Di Fiore B, Makris J, Tsambas A, Stampolidis A, Papadopoulos GA "Exploration of the deep structure of the central Greece geothermal field by passive seismic and Curie depth analysis", 72nd EAGE Conference \& Exhibition incorporating SPE EUROPEC Barcelona, Spain, 1417 June 2010, paper Po12.

Nwankwo CN, Ekine AS. "Geothermal gradients in the Chad Basin, Nigeria, from bottom hole temperature logs". International Journal of Physical Science, 4(12):777-783, 2009.

Obaje N. G.. Geology and Mineral Resources of Nigeria, Lecture Notes in Earth Sciences. Springer Dordrecht Heidelberg, London New York. 221p, 2009.

Obaje, N. G., Balogu, D. O., Idris-Nda, A., Goro, I. A., Ibrahim, S. I., Musa, M. K. Dantata, S. H., Yusuf I., Mamud-Dadi, N. and Kolo I. "A Preliminary Integrated Hydrocarbon Prospectivity Evaluation of the Bida Basin in North Central Nigeria”. Petroleum Technology Development Journal, 3 (2), 36-65, 2013.

Obande GE, Lawal KM, Ahmed LA. "Spectral analysis of aeromagnetic data for geothermal investigation of Wikki Warm Spring, north-east Nigeria". Geothermics 50:85-90, 2014.

Olaniyan, O., Abbah, U., Nwonye, N., Alichi, A. and Udensi, E.E. (Interpretation of Total Magnetic Intensity Field over Bida Basin. Nigerian Geological Survey Agency, Occasional Paper No. 15. 98p, 2012.

Ross HE, Blakely RJ, Zoback MD. "Testing the use of aeromagnetic data for the determination of Curie depth in California". Geophysics 71(5):L51-L59, 2006.

Saleh, S., Salk, M., \& Pamukçu, O. "Estimating Curie point depth and heat flow map for Northern Red Sea Rift of Egypt and its surroundings, from aeromagnetic data". Pure and Applied Geophysics, 170, 863-885, 2013.

Stampolidis A, Kane I, Tsokas GN, Tsourlo PL. "Curie point depths of Albania inferred from ground total field magnetic data". Surv Geophysics 26(4):461-480, 2005.

Tanaka A, Okubo Y, Matsubayashi O "Curie point depth based on spectrum analysis of the magnetic anomaly data in East and Southeast Asia". Tectonophysics 306(3):461-470, 1999.

Tselentis GA “An attempt to define curie depths in Greece from aeromagnetic and heat flow data". PAGEOPH 136:87-101, 1991.

Turcotte DL, Schubert G. Geodynamics: Applications of continuum physics to geological problems" Cambridge University Press. New York, 1982. 